\title{
Evaluation of Drug Procurement with the E-Phurchasing System on the Availability of Drugs at the Pharmacy Installation of the Central Aceh Regency Health Office
}

\author{
Darwin Syamsul ${ }^{1}$, Asriwati Amirah ${ }^{2}, \mathrm{Zikri}^{3}$ \\ ${ }^{1}$ Faculty of Health Pharmacy, Helvetia Institute of Health Medan, Indonesia \\ ${ }^{2}$ Faculty of Public Health, Helvetia Institute of Health Medan, Indonesia \\ ${ }^{3}$ Master of Public Health Study Program, Helvetia Institute of Health, Indonesia \\ Received: October 28, 2021 \\ Received in Revised: December 1, 2021 \\ Accepted: December 7, 2021
}

\begin{abstract}
The purpose of the study was to evaluate drug procurement with the E-Purchasing system on the availability of drugs at the Pharmacy Installation of the Health Office of Central Aceh Regency. The research design used qualitative research methods through in-depth interviews accompanied by direct observation (observation). Informants of the Head of the Health Office, the Head of the Pharmacy Installation of the Health Office, the Planning and Finance Subdivision of the Health Office, the drug management officer at the Health Office and the health center drug management officer were 2 people. Data analysis is presented in the form of a text (content analysis). The results of the research on the availability of drugs at the Pharmacy Installation of the Aceh Tengan District Health Office have not been maximized, the process of ordering drugs by E-purchasing and Non-E-purchasing is in accordance with PMK No. 63 of 2014, but the fulfillment time is not in accordance with the 2014 Pharmaceutical Service Standards. The budget provided for the drug procurement process by e-purchasing is not sufficient. The conclusion of this study is that the availability of drugs in the Pharmacy Installation of the District Health Office of Central Aceh Regency has not been maximized. This drug vacancy is caused by the number of drugs that are not all realized, the time of drug delivery by the distributor.
\end{abstract}

Keywords: Evaluation of Drug Procurement, E-Purchasing System, Drug Availability

\section{Introduction}

The Pharmacy Installation is the Task Unit of the Central Aceh District Health Office in charge of managing drugs, including planning, receiving, storing, distributing, recording, monitoring and evaluating drugs needed for health services at the Puskesmas. The Pharmacy Installation in carrying out its duties serves 17 Puskesmas in Central Aceh Regency (Dewanto, 2015)

Drug is a substance or material that is useful in establishing a diagnosis, preventing, reducing, eliminating, curing disease or symptoms of disease, injury or physical and spiritual disorders in humans or animals, including beautifying the body or parts of the human body (Manusia, 2017). Medicines are an essential component of a health service activity and have become part of the needs of the wider community. Because of the vital need for drugs in health services, correct, efficient and effective drug management is needed by officers at the Center/Province/Regency/City (Hermiana et al., 2017). The drug management process consists of several stages, namely the planning stage, the procurement stage, the distribution stage and the use stage. Because to limit research problems and the stages that are considered to have a very large role in the availability of drugs in a health service are the planning and procurement 
stages of drugs, the focus of this research is more on the problems of the planning and procurement stages of drugs (Safriantini et al., 2011).

Drug procurement is a very important process in pharmaceutical installations. Because in the procurement of drugs, officers must consider in detail and plan in detail about the drug procurement plan that will be carried out (Dewanto, 2015), so that it can achieve the function of the pharmaceutical installation in meeting the need for quality and quality drugs. The importance of drug management in pharmacy installations in achieving optimal health services at the puskesmas, then the drug management process needs to be monitored to find out the weaknesses and strengths in its operational implementation so that corrective action can be taken immediately for the implementation of drug management which is still considered not optimal (Malinggas et al., 2015). The Regency Pharmacy Installation is an important part of services at the Puskesmas, the Regency Pharmacy Installation has the task as a unit that carries out the distribution of drugs directly to the Puskesmas and also has responsibilities in planning, procurement, storage, distribution, maintenance and elimination of drugs that can no longer be used (Suherman \& Nurwahyuni, 2019).

Based on the Directorate of Pharmaceutical and Medical Devices Development, the logistics management system at the Pharmacy Installation consists of the stages of planning, budgeting, procurement, storage, distribution, maintenance, elimination and control that are interconnected with each other so that they must be well coordinated so that each can function effectively. optimal. The disconnect between each stage will result in the supply system and the use of existing drugs being inefficient.

As for the problems that often occur in the drug procurement process, such as the fulfillment of drugs that have not been optimal. Compliance with drugs that are not optimal can cause the availability of these drugs to be less. Availability of too little medicine increases the possibility of stockout. As a result of stockout of drugs, almost every patient, including poor patients, spends more for treatment. Stockout is when the demand for an item or drug cannot be fulfilled due to the unavailability of the drug. To meet the demand for drugs that are many and of good quality and at the right price, it is necessary to procure the right drugs. In this case, the government has issued a policy on drug procurement through the E-Purchasing mechanism based on an electronic catalog (E-Catalogue), which aims to support the government drug procurement process in the JKN era.

The government has provided a drug catalog as an effort to increase effectiveness, efficiency and transparency in the procurement process for drugs for the National Health Insurance program and other program drugs at work units in the health sector, both central and regional, and health facilities, both government and private. All Work Units in the health sector, both Central and Regional and FKTP or FKRTL in the procurement of drugs for both the National Health Insurance program and other health programs no longer need to carry out the auction process, but can directly use the Electronic Catalog (E-Catalogue) system for drugs with the E procedure. -Purchasing (Kemenkes RI, 2014).

Since the era of regional autonomy, it is the responsibility of the regional government to provide and manage public drugs for districts/cities. The district/city health office (DKK) is a regional government work unit in the health sector, one of whose duties and authorities is to provide and manage public medicines for the district/city. Drug procurement is one of the important elements in the drug management cycle which aims to ensure the availability of drugs of standard quality, in the right quantity, and at the lowest possible cost (Kusmini et al., 2016). Research on drug procurement has been widely studied (Winarni, 2006; Iswahyudi, 2007; Puspita, 2009; Pratiwi, 2011). Procurement of drugs by the Health Service is guided by the 
government goods/services procurement regulations regulated in Presidential Regulation Number 54 of 2010 and its derivative regulations. Procurement of drugs available in the list of electronic catalogs (e-catalogue) mandatory purchase method by e-purchasing. If the required drug is not contained in the drug e-catalogue, the procurement process can follow other methods according to government procurement guidelines (Kemenkes RI, 2014).

E-purchasing is one of the electronic-based drug procurement methods (e-procurement). Eprocurement is the use of information technology systems in the automation of the procurement process (Bottani and Rizzi, 2005). E-procurement has been implemented in various countries, as researched by Gunasekaran et al. (2008) in Hong Kong, Teo et al (2009) in Singapore, Eei et al (2012) in Malaysia. The implementation of the e-procurement system in the health sector has been studied by (Kusmini et al., 2016).

The drug e-procurement system based on the e-catalogue is a new drug procurement system in Indonesia that aims to increase transparency, effectiveness and efficiency of the drug procurement process. A few years into the e-purchasing of drugs in Indonesia, various studies have been conducted to determine its implementation. Sutriatmoko et al (2015) conducted an analysis of the application of e-purchasing based on the e-catalogue which aims to study the variables that affect the performance of e-purchasing drugs and the effect of performance on the efficiency of drug procurement in the health office (Sutriatmoko et al., 2015). Ningsih et al (2015) examined the relationship between the application of e-catalogs to the efficiency of procurement and qualitative drug availability in hospitals (Ningsih et al., 2015). Previous research conducted by Dwiaji et al (2016) evaluated drug orders electronically compared to the planned drug needs.

As a relatively new drug procurement system, there are several obstacles in the implementation of drug e-purchasing. Barriers to the implementation of e-purchasing drugs based on ecatalogue, among others, drugs are not available in the e-catalogue, the order is not responded to by the provider's IF while the need is urgent and cannot be postponed, the provider's IF has approved the order but it is only available a few months later or the delivery time is too long, refusal of orders by IF providers due to unavailability of stock, IF providers are subject to administrative sanctions in the form of temporary suspension of activities, operational problems with e-purchasing, private health facilities cannot procure by e-purchasing, payments are delayed, the distributor does not fulfill the agreed delivery time, expiration date product and return of goods, distributors ask for shipping costs, there are no pharmacists in ordering drugs by the health office or puskesmas.

The supply constraints of the provider's IF can cause the realization of e-purchasing of drugs not according to the initial plan. The impact that most often occurs in service facilities due to obstacles to the implementation of e-purchasing drugs is the occurrence of drug vacancies for services, unavailability of drugs for services and potential inefficiency in the budget for drug supply due to non-fulfillment of drug procurement by e-purchasing. Due to the vacancy and scarcity of drugs, almost every patient, including poor patients, pays more for treatment (Kusmini et al., 2016).

The budget for drug procurement at the Central Aceh District Health Office comes from the APBN, which is called the Special Allocation Fund (DAK). (RKA DINKES Central Aceh Regency, 2020). The realization of the Special Allocation Fund for the Procurement of Drugs and Medical Consumables (BMHP) in 2020 only reached $93.16 \%$. Where should the absorption of the Special Allocation Fund (DAK) budget be 100\%. The Special Allocation Fund (DAK) for Drug Procurement Works and BMHP which has not been realized is another $6.84 \%$. This can cause harm to society. (Physical Realization, 2020). 
In 2020 at the Central Aceh District Health Office the percentage of drug availability was 75.78\%. (Central Aceh District Pharmacy Installation. 2020). Meanwhile, the Directorate General of Pharmacy and Medical Devices has set a target of achieving 95\% of drug availability by 2020 (Kemenkes RI, 2020). From the data above, we can see that the performance indicators that have been set by the government have not yet met the target. From the document review at the Pharmaceutical, Medical Devices and PKRT Sections, 17 drug procurement contracts with distributors were found. Of the 17 contracts, there are 3 contracts that have problems with realization. (List of Drug Procurement Realization, 2020). Affects health services at the Puskesmas because the puskesmas is the spearhead of basic health services to the community if the drugs available at the health service are not adequate it will have an impact on drug services to patients at the puskesmas so that patients have to buy the drugs they need outside, this is contrary to the health insurance program National Health Insurance (JKN) where the government guarantees the availability of free medicines.

Based on the above background, the researcher aims to evaluate drug procurement with the EPurchasing system on the availability of drugs at the Pharmacy Installation of the Central Aceh District Health Office 2021. The results of this study are expected to provide input for improving the implementation of drug E-Purchasing in Indonesia.

\section{Methods}

This type of research uses qualitative methods through in-depth interviews accompanied by direct observation (observation) with a case study design. Researchers will use informants to obtain various information needed during the research process using the Purposive Sampling Technique. Qualitative data analysis is carried out by content analysis. Data analysis through data reduction, data presentation and conclusion drawing. The informants in this study were: 1) Head of Health Office of Central Aceh Regency, 2) Head of Pharmacy Installation of Central Aceh District Health Office, 3) Planning and Finance Subdivision of Central Aceh District Health Office. 4) Drug Management Officer at Central Aceh District Health Office and 2 (two) health center drug managers.

\section{Results and Discussion}

\section{Drug Procurement at the Pharmacy Installation of the Central Aceh District Health Office}

Drug procurement carried out at the Pharmacy Installation of the Central Aceh District Health Office has used drug procurement with the E-purchasing procedure based on the E-catalogue.

\section{Stock (Inventory)}

Procurement is one of the activities to carry out planning and determining drug needs at the Health Office.

In the organization of reporting and recording, it must be clear so that reporting of drug entry and exit can be known by the Head of the Central Aceh District Health Office. In order for medicines to be seen for availability, it is necessary to record and make stock cards and input them on the computer so that they are recorded and easy to find and easier to report. In order for reporting to be easy, the recording of drugs in and out must be clear, so that reporting is also clear. In recording the entry and exit of drugs, it must be clear for reporting, but it is better for the records to be recorded on a computer in order to avoid missing records. A good report should be recorded properly so that the request or procurement of new drugs is easier and there are no unclear reports. The Community Health Center (puskesmas) has made clear bookkeeping so that drug reporting is very clear, this is to make it easier to procure back.

Copyright @ 2021 , Journal of Asian Multicultural Research for Medical and Health Science Study, Under the license CC BY-SA 4.0 
The grouping of types of drug preparations has been informed and a report has been made. The grouping of types of drug preparations at the Health Office of Central Aceh Regency has been made in alphabetical form and made in the form of stock cards. The grouping of types of drug preparations in the Planning and Finance Subdivision of the Health Office of Central Aceh Regency has been made in alphabetical form and made in the form of stock cards. For the drug procurement process, the Central Aceh Health Office starts from planning a drug purchase proposal and then submits it to the planning division according to existing procedures. For drug management, the health center calculates the need for drugs and then submits them to the health office according to the procedure. For drug management, the health center calculates the need for drugs and then submits them to the health office according to the procedure.

For every month reporting of drug availability is always reported by recording and reporting on a regular basis every month. The separation of drugs is carried out when incoming goods are not carried out monthly, in order to facilitate the control of drugs based on the budget year and ED, to facilitate and be checked by the BPK RI audit team every year. Similarly, the Health Office in the Planning and Finance Subdivision of drugs is also separated based on the budget year and the ED. To limit the planning section to procure drugs from ordering to processing payments. The availability of drugs from the health office is still insufficient because the availability of drugs at the health office is also limited. The availability of drugs from the health office is still insufficient because the availability of drugs at the health office is also limited

Communications made by the Head of the Central Aceh District Health Office have been carried out so that problems related to drug stocks can be taken out and solutions. For rechecking of drugs carried out by the health office, they provide a report on the remaining stock of existing drugs which will be used as a reference in the next drug procurement. The sorting of drugs is done so that further orders for drugs are easier to record and the amount to be added is clear. For inspection, it is directly checked by the planning department before making payments to distributors. The puskesmas expects that capitation funds will always be rotated, but capitation funds are also needed for others so that drug procurement is not maximized. The puskesmas expects that capitation funds will always be rotated, but capitation funds are also needed for others so that drug procurement is not maximized.

The policy carried out by the Head of the Central Aceh District Health Office is to always communicate to the government about the availability of funds for drug procurement. For reporting expired drugs, special actions are taken before further action is taken by the next party. Drug checks are always carried out so that the availability of existing drugs is monitored so that shortages can be minimized. The problems and constraints faced are that many of the items we need are not available at ecataloq, the long delivery times cannot be predicted, the drugs that are meant to be ed are too close, some medicines are not supplied until the time specified for various reasons such as the absence of medicinal raw materials. There are still obstacles from the puskesmas that they do not understand what e-purchasing is, they still use manuals with regular records. They also think that what is important is that the medicine is fulfilled to the maximum. There are still obstacles from the puskesmas that they do not understand what e-purchasing is, they still use manuals with regular records. They also think that what is important is that the medicine is fulfilled to the maximum.

Reports for expired drugs are always reported to the Central Aceh District Health Office. Recording of expired drugs is carried out by recording themselves before being followed up.

Based on the explanation above, it is concluded that the needs planning process starts from the supply coordinator making a compilation of usage with the consumption method and then after being submitted to the head of the pharmaceutical installation, it will be determined to the type 
of procurement based on the needs planning made. So that it can separate purchases with Ecatalogue and non-E-catalogue.

Based on needs planning, it is carried out to avoid drug shortages by using methods that are accountable and the basics of planning that have been determined include consumption, epidemiology, combination of consumption and epidemiological methods and adjusted to the available budget. Planning guidelines should also consider available budgets, prioritization, remaining inventory, past period usage data, order lead times, and development plans.

Based on in-depth interviews conducted and the results of a document review of the working procedure for planning drug needs at the Pharmacy Installation of the Health Office of Central Aceh Regency, it is known that the Pharmacy Installation of the Health Office of Central Aceh Regency uses the Consumption method in determining the plan for drug needs in the Pharmacy. The Consumption Method is a method that is based on the analysis of the previous year's drug consumption data so that later the results will get the required amount of drug. To obtain data on drug demand that is close to accuracy, it is necessary to analyze the trend of drug use in the previous 3 (three) years or more. In addition, data are also needed such as drug lists, early pretentiousness, receipts, expenditures, remaining stock, lost/damaged drugs, expired, drug vacancies, average usage, waiting time, safety stock, and development of visiting patterns.

This data is needed to perform calculations using the consumption method. Planning using the consumption method is indeed one of the ways in standard Pharmacy services, but for the purpose of planning itself this method is still not appropriate to use, because there are still drug vacancies in the Health Office. It was also found in research conducted by Rahmawati (2015) and Badarudin (2015) that the planning of drug procurement using the consumption method was not in accordance with the needs and could not be used as a basis for assessing drug use so that there was often a shortage of drug stocks at the Pharmacy Installation. The Health Office of Central Aceh Regency has planned drug needs using one of the methods in the 2014 Pharmaceutical Service Standards, but the planning carried out by planning officers is still not in accordance with the purpose of planning drug needs, namely avoiding drug vacancies.

\section{Reordering Level}

The process of ordering drugs at the Pharmacy Installation of the Health Office of Central Aceh Regency is divided into two, namely ordering using the E-purchasing procedure based on the E-catalogue and ordering using the non-E-purchasing or non-E-catalogue procedure.

For the purchase of drugs made by the Head of the Central Aceh District Health Office, it is carried out at the beginning of the month for the needs of the next year. Similar to the Health Office, the Pharmacy Installation of the Health Office also makes repurchases at the beginning of the month for the need for 1 year in the future according to the proposed data from the puskesmas. Drug needs are ordered at the beginning of the month for the needs of the next 1 year. Re-ordering of drugs based on the health office, namely at the beginning of the month and for the needs of the next 1 year.

Drug management is carried out based on the calculation of consumption patterns, drug use at the puskesmas. For drug managers use consumption patterns for calculations according to usage every year. For drug managers use consumption patterns that are reported every month. For drug managers use consumption patterns for calculations according to usage every year.

The calculation of ROP is not based on computerized reports, but on the calculation of drug needs and consumption patterns. There are many problems faced by the Pharmacy Installation of the Health Office, one of which is the availability of drugs in the drug e-cataloq. For the 
calculation of ROP, it is not based on computerized reports, but the calculation of drug needs and consumption patterns and from the puskesmas is calculated manually. Drug distributors who determine our manufacturers place orders for factory drugs through the e-cataloq and epurchasing systems.

For the supply of drugs, we do not use existing distributors, but based on the manufacturer's decision, so after we order the drug to the manufacturer, it will appear later. The supply of drugs is very far from what is expected, it is very rare for distributors to supply drugs on time. One of the Pharmacy Installations at the Health Office is the availability of drugs in the drug e-cataloq. The supply of drugs is very far from what is expected, it is very rare for distributors to supply drugs on time. The supply of drugs is very far from what is expected, it is very rare for distributors to supply drugs on time.

The process of ordering drugs carried out by the Pharmacy Installation of the Health Office of Central Aceh Regency is carried out using the E-purchasing method, but if you face several obstacles, purchases will be made outside of E-purchasing. Purchasing using the E-purchasing procedure at the Pharmacy Installation of the Health Office of Central Aceh Regency goes through how many stages, Based on the technical guidelines for Procurement of Drugs based on the E-catalogue Starting from the PPK, making a procurement implementation plan (this plan starts with pharmaceutical planning in the warehouse), then the procurement official logs in on the website and select the E-procrument and E-purchasing application to make a package, then input and send purchase request purchase data, after sending the purchase request, the purchase agreement will be sent from the provider in the form of rejection or acceptance, after which a contract agreement and contract execution will be carried out .

The compliance of drug providers or distributors in drug procurement regulations based on the E-catalogue is indeed still very low, this can be seen from the fact that distributors often do not apply the rules that have been set.

The delay in ordering made by the procurement officer was due to a late submission from the Health Service Pharmacy Installation, this was because the warehouse was still using the manual system, so submissions were often made when the drug stock ran out. There is no connected system in the drug warehouse, causing no warning if the stock has entered the minimum or small amount.

Based on the explanation above, it is known that the Pharmacy Installation of the Central Aceh District Health Office has implemented an E-purchasing and Non-E-purchasing drug ordering process in accordance with PMK No. 63 concerning Procurement of drugs based on Ecatalogue by E-purchasing, but the time for ordering drugs is often delayed due to waiting for the DPA (Budget Execution Document) to come out and there is no information system that warns if the drug has entered the minimum amount.

\section{Economic Order Quantity}

This is based on interviews with two informants, both of whom stated that the available funds were not maximized.

To procure drugs based on drug needs and consumption patterns. To procure drugs based on drug needs and consumption patterns. To procure drugs based on drug needs and consumption patterns. Procurement of drugs is not based on the calculation of the consumption method or the epidemiological method, but according to the recommendation of the health office drug manager. 
Ensuring the availability of drugs at the health office, the health office always prepares a budget every year so that the budget remains and communicates with the government how the availability of drugs at the health office. For the ABC method, it is clear that it is very precise and more accurate to see the existing drug needs and existing stock and it is easier to coordinate if the drug stock is lacking. For the $\mathrm{ABC}$ method, it is clear that it is very precise and more accurate to see the existing drug needs and existing stock and it is easier to coordinate if the drug stock is lacking. The availability of drugs has not been maximally available, this is related to the budget issued by the government.

All records have been computerized in the Ministry of Health application to make it easier to control drug stock needs. To ensure the availability of drug stock, always perform calculations so that drug availability remains available. To ensure the availability of drug stock, orders are made at the beginning of the month for the needs of the next 1 year. All drug orders are made using e-cataloq and e-purchasing systems.

All drug orders are made using e-cataloq and e-purchasing systems. All records have been computerized in the Ministry of Health application to make it easier to control drug stock needs. All drug orders are made using e-cataloq and e-purchasing systems.

The budget provided by the Pharmacy Installation of the Aceh Tengah District Health Office for procurement has been provided. This budget is sourced from APBD funds. Based on indepth interviews, the budget provided is the budget for general procurement, both E-purchasing and non-E-purchasing. The budget that has been provided is sufficient to carry out procurement activities and the overall budget that has been planned at the hospital besides that every year the budget for procurement increases. So far, there have been no constraints related to the budget provided because the hospital has not experienced a lack of funds when purchasing drugs.

In addition, the budget is also seen in terms of its use or use based on in-depth interviews conducted with several procurement officers, it is known that the maximum utilization of funds has been carried out, the funds used are not left over, all funds are spent on purchasing drugs by e-purchasing and non-e-purchasing. so that the budget provided has been used optimally for drug procurement by e-purchasing. Based on the explanation above, it is known that the Pharmacy Installation of the Central Aceh District Health Office does not yet have sufficient budget to procure drugs by e-purchasing, and has made maximum use of funds to procure drugs by e-purchasing.

\section{Drug Procurement by E-purchasing}

Procurement of drugs by E-purchasing is one way in the purchasing process set by the government to meet the needs of health facilities such as health centers in the need for quality drugs and at appropriate prices. In the Department of Health, drug procurement activities are part of the pharmaceutical management cycle. Drug procurement activities at the Health Office are the responsibility of the district pharmacy installation (Minister of Health Regulation, 2014)

\section{Conclusion}

The availability of drugs at the Pharmacy Installation of the District Health Office of Central Aceh Regency has not been maximized. This drug vacancy is caused by the number of drugs that are not all realized, the time of drug delivery by distributors, there has been a national drug void, and the absence of an information system that can warn of the number of drugs that enter the minimum stock, so that the submission of orders is not too late. The process of ordering drugs by E-purchasing and Non-E-purchasing at the Pharmacy Installation of the Health Office

Copyright (C) 2021, Journal of Asian Multicultural Research for Medical and Health Science Study, Under the license CC BY-SA 4.0 
of Central Aceh Regency is in accordance with PMK No. 63 of 2014, but the fulfillment time is not in accordance with the 2014 Pharmaceutical Service Standards. The budget provided by the Government for the Pharmacy Installation of the Central Aceh District Health Office for the drug procurement process by E-purchasing is not sufficient.

\section{References}

Dewanto, S. (2015). Analisis Pengadaan Obat Berbasis Pareto dan Ven dengan Metode Economic Order Quantity Terhadap Efisiensi Biaya di Instalasi Farmasi RS PKU Muhammadiyah Bantul.

Hermiana, A., Robiyanto, \& Nurmainah. (2017). Evaluasi Implementasi Pengadaan Obat Berdasarkan Sistem Katalog Elektronik (E-Catalogue) di Kabupaten Sintang Tahun 2015. Farmasains, 4(2), 57-63.

Kemenkes RI. (2014). Peraturan Menteri Kesehatan Republik Indonesia Nomor 63 Tahun 2014 tentang Pengadaan Obat Berdasarkan Katalog Elektronik (E-catalogue).

Kusmini, Satibi, \& Suryawati, S. (2016). Evaluasi Pelaksanaan E-Purchasing Obat Pada Dinas Kesehatan Kabupaten/Kota Di Jawa Tengah Tahun 2015. JURNAL MANAJEMEN DAN PELAYANAN FARMASI (Journal of Management and Pharmacy Practice), 6(4), 277. https://doi.org/10.22146/jmpf.357

Malinggas, N. E. R., Soleman, T., \& Posangi, J. (2015). Analisis Manajemen Logistik Obat di Instalasi Farmasi Rumah Sakit Daerah DR Sam Ratulangi Tondano. Artikel Penelitian JIKMU, 5(2b), 448-460.

Manusia, P. P. S. D. (2017). Farmakologi Bahan Ajar Rekam Medis dan Informasi Kesehatan (RMIK).

Ningsih, A., Fudholi, A., \& Sumarni. (2015). Hubungan Penerapan Elektronik Katalog Terhadap Efisiensi Pengadaan dan Ketersediaan Obat. Jurnal Manajemen Dan Pelayanan Farmasi, 5(4), 241-.

Peraturan Menteri Kesehatan Republik Indonesia Nomor HK.02.02/MENKES/068/I/2010 Tentang Kewajiban Menggunakan Obat Generik Di Fasilitas Pelayanan Kesehatan Pemerintah. (2010).

Safriantini, D., Ainy, A., \& Mutahar, R. (2011). Analisis Perencanaan dan Pengadaan Obat di Puskesmas Pembina Palembang. Jurnal Ilmu Kesehatan Masyarakat, 2(1), 30-38.

Suherman, \& Nurwahyuni, A. (2019). Analisa Pengelolaan Kebutuhan Logistik Farmasi pada Instalasi Farmasi RS MBSD Periode Juli 2017- Juni 2018. Jurnal Administrasi Rumah Sakit Indonesia, 5(2), 49-58.

Sutriatmoko, Satibi, \& Puspandari, D. A. (2015). Analisis Penerapan E-Procurement Obat Dengan Prosedur E-Purchasing Berdasar E-Catalogue di Dinas Kesehatan Kabupaten / Kota Di Jawa Tengah. Jurnal Manajemen Dan Pelayanan Farmasi, 5(4), 275-. 